\title{
Training entrepreneurship to adapt to local economic development
}

\author{
Yubo-Cui \\ DaQing, HeiLongjiang province, China \\ DaQing Normal College,HeiLongjiang province, China \\ Email:jiaoyanke5510268@126.com
}

\begin{abstract}
The difference between entrepreneurship education and traditional education is the ability of students entrepreneurship. It shows essential demand of knowledge, quality, ability for talents. University is the main force of higher education, talents are the last "step" to export . The society takes focus attention on their quality and ability especially innovation and entrepreneurship ability. The ability is a core element and difficulty for us. How to train entrepreneurship ability? How to improve our teaching quality? We should build an innovation system and train talents with entrepreneurial spirit. It is important not only for our local economic and social development, but also for school's sustainable development.
\end{abstract}

Keywords: innovation, entrepreneurship, local economy.

\section{培养适应地方经济发展的创新创业人才

\author{
崔玉波 \\ 大庆师范学院经济管理学院, 大庆, 黑龙江, 中国 \\ Email: jiaoyanke5510268@126.com
}

\begin{abstract}
摘要.创新创业教育与传统教育的根本区别 在于突出了学生创新创业能力的培养, 体现 了社会经济发展对人才知识、素质、能力结 构的根本性要求。大学作为高等教育的主力 军, 人才“商品生产”的出口或最后一道“工 序”，其创新创业能力是 “市场品质、品牌” 的核心元素, 是社会关注的焦点, 更是高校
\end{abstract}


关键词: 创新; 创业; 地方经济

1989 年 11 月在北京召开的 “面向 21 世纪教育国际研讨会” 上首次提出创业教育 概念。与会代表要求把创业教育和学术教 育、职业性教育提高到同等重要地位。国际 上一些发达国家对创业教育非常重视, 美国 的创业教育已被纳入国民教育体系之中, 内 容涵盖了从小学、初中、高中、大学专科、 本科直到研究生的正规教育。世界经济合作 和发展组织的专家柯林 - 博尔将创业教育总 结为: 未来的人应掌握的 “第三本教育护 照”。而我国高校创新创业教育的实施始于 20 世纪末。1998 年, 清华大学举办首届清 华大学创业计划大赛, 成为第一所将大学生 创业计划竞赛引入亚洲的高校。2002 年, 高校创业教育在我国正式启动, 教育部将清 华大学、中国人民大学、北京航空航天大学 等 9 所院校确定为开展创业教育的试点院 校。

2010 年, 教育部在《关于大力推进高 等学校创新创业教育和大学生自主创业工 作的意见》中指出: “在高等学校开展创新 创业教育, 积极鼓励高校学生自主创业, 是 教育系统深人学习实践科学发展观, 服务于 创新型国家建设的重大战略举措; 是深化高 等教育教学改革, 培养学生创新精神和实践 能力的重要途径; 是落实以创业带动就业, 促进高校毕业生充分就业的重要措施”。

2012 年 8 月教育部印发了《普通本科 学校创业教育教学基本要求 (试行)》的通 知。对普通本科学校创业教育的教学目标、 教学原则、教学内容、教学方法和教学组织 作出了明确规定。创业教育的教学目标是要 使学生掌握创业的基础知识和基本理论, 熟
悉创业的基本流程和基本方法, 了解创业的 法律法规和相关政策, 激发学生的创业意 识, 提高学生的社会责任感、创新精神和创 业能力, 促进学生创业就业和全面发展。十 多年来, 创新创业教育逐步引起了各高校的 重视,一些高校在国家有关部门和地方政府 的积极引导下, 进行了积极有益的探索与实 践。目前国内高校的创新创业教育主要形式 是以创业设计类竞赛为载体, 开展创新创业 教育。如 “挑战杯” 创业经营模拟大赛; 以 大学生就业指导课为依托, 开展创新创业教 育; 通过成立大学生创业基地 (园区) 为平 台, 开展创新创业教育;

以人才培养模式创新实验区为试点, 培 养创新型人才; 搭建创新创业教育课程体 系, 实施创新创业教育; 将创新课程融入人 才培养方案, 全面实施创新创业教育等形 式。但是关于创新创业人才培养教育体系的 系统研究与实践, 相关报道较少构建创新创 业教育体系, 达到提高学生创新创业能力的 目的, 具有较强理论研究意义和实践应用价 值。

创新创业教育与传统教育的根本区别 在于突出了学生创新创业能力的培养, 体现 了社会经济发展对人才知识、素质、能力结 构的根本性要求。大学作为高等教育的主力 军, 人才 “商品生产” 的出口或最后一道“工 序”, 其创新创业能力是 “市场品质、品牌” 的核心元素, 是社会关注的焦点, 更是高校 深化改革, 提高办学质量的热点与难点。

目前对于地方高校创业教育还处于初 期阶段, 培养学生的创业意识, 树立创业理 念, 开设并逐步完善创业课程体系尤为重 要。伴随着互联网经济的发展, 大学毕业生 们深感就业压力的强大, 创业教育逐渐被高 
校认可并随之发展。创业教育不是一蹴而就 的, 不是把国外创业教育模式搬来就可以应 用的。我国有我国的国情, 各个地区的经济 发展模式也不尽相同。地方高校应结合地方 区域经济的发展制定自己的创业教育模式。 地方高校目前以培养应用型人才为目标, 注 重学生的实践能力。如果将实践教学与创业 教育完美的结合将是发展地方高校创业教 育的途径之一。

培养适应地方经济发展的创新创业人 才, 构建创新型人才培养体系, 以创新创业 教育为核心, 培养具有创新、创业精神和实 践能力的高素质人才, 不仅是国家构建创新 体系对高校的根本要求, 也是服务地方经济 和社会发展的现实需要、更是学校自身可持 续发展的必然选择。开展创新创业教育要从 以下方面着手:

1. 要培养学生创新创业意识。

创业需要激情, 需要动力。学校要将创 业理念贯穿给学生, 使学生树立创业观念, 培养创新精神。通过调整相关理论课程或完 善课程内容, 在课堂教学中, 加强创新创业 知识的讲解, 使学生掌握创新创业的基本知 识, 了解创建企业的基本流程, 正确认识并 理解创新创业的内在要求, 启蒙学生的创新 意识和创业精神, 使学生了解创新型人才的 素质要求, 了解创业的概念、要素与特征等, 让学生掌握开展创业活动所需要的基本知 识, 激发学生创新创业动力, 增加创新创业 意识。为学生的创业奠定理论基础。

2. 给学生创造创业条件的同时让学生 对创业环境有所认知。

通过开展实习、见习、实地调研创业企 业等社会实践教学环节, 加强学生与社会、 与企业的接触, 从而最直观的感受创新创业
的外部环境, 引导学生认知当今企业及行业 环境, 了解创业机会, 把握创业风险, 掌握 商业模式开发的过程, 设计策略及技巧, 为 其合理确定创新创业目标、途径与方法奠定 基础。

3. 提升学生创新创业能力。

以实验室、校内外创新创业实践基地为 平台, 通过开展专业技能训练、创新实践活 动、第二课堂活动、课外科技活动, 组织开 展学科竞赛等方式, 解析并培养学生的批判 性思维、洞察力、决策力、组织协调能力与 领导力等各项创新创业素质, 提高其创新创 业基本知识、技巧、技能。

\section{4. 学生模拟创新创业实践。}

通过鼓励学生申报各级创新创业项目、 开展校园商贸文化节等活动, 进行创新创业 实践模拟，通过创业计划书撰写、模拟实践 活动开展等, 鼓励学生体验创业准备的各个 环节, 包括创业市场评估、创业融资、创办 企业流程与风险管理等, 培养学生创新创业 实际运用能力 (实践能力) 。通过实践开展 创业实战演练, 使学生在情景模拟当中熟悉 创业过程。

5. 建立实施大学创新创业训练计划的 运行管理机制

按 “总体设计, 分项实施” 的原则, 组 织实施各创新创业教育教学环节, 将创新创 业教育贯穿于整个人才培养过程, 做到从低 年级到高年级进行渐进式培养提高, 大学四 年培养不断线。同时建立大学生创新创业训 练计划组织实施机构, 将各教学环节纳入日 常教学和管理工作中, 从而建立长效机制。

6. 师资和培训

培养创业型的师资队伍, 对教师进行实 践培训是创业教育的一个重要环节。提高教 
师的指导能力, 增强教师的创业实践能力才 能够有效的对学生进行指导, 利于师生互 动。

总之,创业教育的灌输不是一蹴而就的, 需要逐步发展提高学生的创业能力, 为地方 经济发展服务。

\section{致谢}

本文为黑龙江省教育教学改革项目《基于中国 大学视频公开课的通识选修课教学设计与实践》和 大庆师范学院教育教学改革项目《地方高校市场营 销专业创新创业教育体系的构建与实施》的阶段性 成果之一。

\section{References}

[1] Zhuxiu-Zhang, Examine on American Students entrepreneurship and entrepreneurship education [J]. Chinese Students' Employment. 2009 (13)

[2] Dongchun-Xiang,Yunlong-Xiao. Features of Entrepreneurship Education in American and Boston [J]. Modern University Education. 2003 (02)

[3] Zhi-Hao,Situation of College Students 'Entrepreneurship Education and Countermeasures [J]. Chinese Students' Employment. 2009 (04)

[4] Lanxiao-Du,Yongliang-Gao.Characteristi cs of foreign entrepreneurship education and enlightenment to China $[\mathrm{J}]$. Chinese School Education (theory). 2009 (01)

[5] Huaping-Xu, Entrepreneurship Education in Chinese Universities [J] China Higher Education Research. 2004 (02) 